\title{
BENTUK TES TOEFL UNTUK MAHASISWA UNIVERSITAS KALTARA: STUDI KUALITATIF
}

\author{
Aries Utomo ${ }^{1}$ dan Puardmi Damayanti ${ }^{2}$ \\ ${ }^{1,2}$ Universitas Kaltara \\ Jalan Sengkawit RT.23, Tanjung Selor, Kab. Bulungan, Indonesia \\ Surel: aries.utomo91@gmail.com1 Telp:+6285247083459
}

Submitted: 20xx-mm-dd

Accepted: 20xx-mm-dd

Published: 20xx-mm-dd

\begin{tabular}{ll}
\hline Keywords: & Abstract \\
\hline TOEFL, skills & TOEFL is one of the tests used to measure a person's level of \\
language of & English with three forms of tests, namely (1) listening \\
English, Kaltara & comprehension, (2) structure and written expression, and (3) \\
University & reading comprehension. In addition to being used as a requirement \\
& when applying for a job, the test is also used by students for the \\
& purpose of college or as a condition for graduation. However, there \\
& are several universities that do not carry out these tests, one of \\
& which is Kaltara University. This study aims to describe kinds of \\
& TOEFL tests which are able to work by Kaltara University students. \\
& The research method used is qualitative. This study uses data \\
& collection techniques, namely: (1) observation, (2) interviews, and \\
& (3) document analysis. The data analysis techniques used are Miles \\
& and Huberman Models. The results of this study indicate that (1) the \\
& hardest test done by the students is listening, meanwhile the easiest \\
& test done is structure and written expression; and (2) the ability of \\
& Kaltara University students had an average TOEFL score, 460 \\
& which was categorized as a minimum standard. Therefore, there \\
& needs to be an increase in TOEFL scores for Kaltara University \\
& students.
\end{tabular}

\section{PENDAHULUAN}

TOEFL atau dikenal dengan Test of English as a Foreign Language merupakan sebuah tes bahasa Inggris yang digunakan untuk mengukur tingkat penguasaan bahasa Inggris seseorang melalui listening, writing and structure expression, dan reading test. Menurut Sukur (2013), TOEFL merupakan salah satu jenis tes standar untuk menguji kemampuan bahasa Inggris seseorang sebagai syarat mutlak untuk melanjutkan pendidikan ke jenjang yang lebih tinggi di hampir semua perguruan tinggi di dunia, termasuk di Indonesia. Di Indonesia, penggunaan TOEFL sebagai tes profisiensi bahasa Inggris cukup luas, dari yang sekadar untuk mengetahui kekuatan diri seseorang dalam penguasaan bahasa Inggris sampai tujuan-tujuan penting seperti memasuki program pendidikan dan melamar pekerjaan. 
Keutamaan dari universitas dan Sekolah Tinggi di negara asing seperti Amerika Bagian Utara dan negara berbahasa Inggris lainnya mewajibkan laporan hasil skor TOEFL secara resmi untuk pendaftaran. Tes tersebut juga digunakan oleh insitusi dari Negara lainnya dimana bahasa Inggris adalah bahasa instruksi. Ditambah lagi, agen pemerintah, program beasiswa dan agen sertifikat berlisensi menggunakan nilai TOEFL untuk mengevaluasi kemampuan berbahasa Inggris. Keberterimaan nilai tergantung pada institusi tertentu atau agen yang terlibat.

Menurut Sugeng, et al. (2012) penyelenggaraan pengukuran penguasaan bahasa Inggris bagi mahasiswa baru adalah langkah penting yang perlu diambil oleh tiap universitas di Indonesia. Istilah kata penguasaan bahasa seseorang disebut profisiensi yang mengandung arti seberapa tinggi penguasaan bahasa seseorang pada suatu saat tertentu (Creswell, 2008; Weir,2005). Untuk mengukur profisiensi bahasa seseorang, digunakan perangkat tes bahasa yang disebut tes penguasaan bahasa (language roficiency test). Salah satu tes profisiensi bahasa Inggris yang banyak digunakan di dunia adalah TOEFL.

Dalam Genius Edukasi (2015) dijelaskan bahwa TOEFL terbagi atas beberapa jenis, yaitu (1) PBT adalah bentuk TOEFL yang paling konvensional. Sistem tesnya menggunakan lembaran kertas soal dan jawaban yang harus diisi dengan pensil 2B. Materi yang diujikan adalah listening, structure, dan reading. (2) Computer Based Test (CBT) adalah bentuk yang lebih praktis dari Paper Based Test (PBT). Sistem tes TOEFL CBT tidak lagi menggunakan kertas, tapi dengan komputer. Semua soal ditampilkan di layar menggunakan software interaktif. Peserta dapat langsung mengerjakan di komputer. Materi yang diujikan adalah listening, structure, reading, dan writing. (3) Internet Based Test (iBT) adalah bentuk terbaru yang menggunakan komputer dan internet sebagai medianya. Materi tes yang diujikan adalah reading, listening, writing, dan speaking. Materi structure tidak hilang, tapi melebur ke dalam empat materi lainnya. Soal yang diujikan tidak hanya independent test (tes individual), tetapi juga integrated test (tes kombinasi). Tes kombinasi berarti dalam satu soal ada lebih dari satu materi. Misalnya sebuah paragraf (reading) diikuti dengan penjelasan seseorang tentang paragraf tersebut (listening). Lama waktu tes adalah 4 jam. Dari ketiga jenis TOEFL yang dijelaskan di atas dapat dirangkum pada Tabel 1, sebagai berikut:

Tabel 1. Jenis TOEFL

\begin{tabular}{|c|c|c|}
\hline TOEFL PBT & TOEFL CBT & TOEFL iBT \\
\hline Menggunakan media kertas. & Menggunakan media komputer. & $\begin{array}{l}\text { Menggunakan media } \\
\text { komputer dan internet. }\end{array}$ \\
\hline Skala penilaian $310-677$ poin. & Skala penilaian $0-300$ poin. & $\begin{array}{l}\begin{array}{l}\text { Skala penilaian } 0-120 \\
\text { poin. }\end{array} \\
\end{array}$ \\
\hline $\begin{array}{c}\text { Test of written English (TWE) } \\
\text { jarang dipakai sebagai materi } \\
\text { ujian. }\end{array}$ & $\begin{array}{c}\text { TWE selalu ada dengan nama } \\
\text { writing section yang skornya } \\
\text { digabung dengan skor structure. } \\
\text { Bobot nilainya masing-masing } 50 \\
\text { persen. }\end{array}$ & $\begin{array}{l}\text { TWE selalu ada dengan } \\
\text { nama writing section, } \\
\text { tetapi tes structure } \\
\text { ditiadakan. }\end{array}$ \\
\hline Tidak ada tes speaking. & Tidak ada tes speaking. & $\begin{array}{c}\text { Ada tes speaking. Pada tes } \\
\text { ini, peserta akan berbicara } \\
\text { lewat mikrofon. }\end{array}$ \\
\hline $\begin{array}{l}\text { Tes dimulai setelah kuota } \\
\text { peserta terpenuhi. }\end{array}$ & $\begin{array}{c}\text { Tes dapat dimulai kapan saja, } \\
\text { tanpa menunggu adanya peserta } \\
\text { lain. }\end{array}$ & $\begin{array}{l}\text { Tes dapat dimulai kapan } \\
\text { saja, tanpa menunggu } \\
\text { adanya peserta lain. }\end{array}$ \\
\hline Harga paling murah & Harga sedikit lebih mahal. & Harga paling mahal. \\
\hline
\end{tabular}


Selain itu, bentuk tes pada soal TOEFL terbagi atas tiga tes (Philips, 2001:14), yaitu: (1) Listening Comprehension, tes ini bertujuan untuk mendemonstrasikan kemampuan dalam memahami permbicaraan berbahasa Inggris, orang yang diuji harus mendengar tipe pembicaraan yang bervariasi pada sebuah rekaman dan merespon dengan memilih pilihan ganda yang telah disediakan. (2) Structure and Written Expressions. Tes ini bertujuan untuk mendemonstrasikan kemampuan dalam mengenali bahasa Inggris yang benar secara gramatikal, orang yang diuji harus memilih jawaban yang benar untuk melengkapi kalimat atau menemukan kesalahan dalam kalimat. (3) Reading Compehension. Untuk mendemonstrasikan kemampuan dalam memahami bahasa Inggris tertulus, orang yang diuji harus menjawab pertanyaan pilihan ganda tentang ide dan makna dari kata-kata yang ditemukan pada artikel bacaan. Terkait dengan penjelasan tersebut, dapat dirangkum pada Tabel 2 sebagai berikut.

Tabel 2. Bentuk Tes TOEFL

\begin{tabular}{ccc}
\hline Bentuk Tes & Jumlah Pertanyaan & Waktu \\
\hline Listening Comprehension & 50 butir soal & 35 menit \\
\hline $\begin{array}{c}\text { Structure and Witten } \\
\text { Expression }\end{array}$ & 40 butir soal & 25 menit \\
\hline Reading Comprehension & 50 butir soal & 55 menit \\
\hline
\end{tabular}

Dalam mengerjakan sesuatu diperlukan sebuah trik agar berhasil dalam menyelesaikannya, begitu juga dengan TOEFL. Stafford-Yilmaz \& Zwier (2005) berpendapat bahwa ada enam cara sukses pada TOEFL, yaitu: mencoba untuk memahami sebuah artikel atau perkuliahan secara keseluruhan, membuat catatan, mempelajari Grammar pada konteksnya bukan pada Grammar tersebut, berlatih menulis essai yang mengekspresikan pendapatmu pada sebuah topik, membangun kosakata akademik, dan komit perhatian pada tes. Selain itu, menurut Saafin (2014) untuk menginvestigasi kemampuan mahasiswa dalam berbahasa, diperlukan suatu tes yaitu TOEFL yang mampu menentukan level dalam mempelajari bahasa Inggris. Sebagai contoh penelitian yang telah dilakukan oleh Sucahyo (2016) di IAIN Samarinda diperoleh bahwa mahasiswa memiliki masalah dalam mencapai nilai TOEFL dengan nila rata-rata 397 yang masih dikategorikan basic (elementary). Hal itu terjadi karena kendala terbesar mahasiswa dalam mengerjakan TOEFL adalah pada bagian menyimak (listening).

Menurut sumber lain (Cheng \& Ma, 2015) untuk mengetahui persepsi pelajar terkait dengan nilai dari pelatihan tes persiapan TOEFL siswa perlu mendapatkan sebuah perubahan persepsi terkait nilai dan kebutuhan untuk peningkatan kemampuan bahasa Inggris secara umum dan mempertahankan sebuah persepsi instrumental yang berfokus pada pencapaian nilai yang kurang pada seleksi penelitian melalui kursus persiapan tes.

Terkait dengan tes tersebut, banyak orang yang beranggapan bahwa TOEFL sulit untuk dikerjakan. Bahkan, di beberapa kampus, TOEFL hampir tidak pernah diajarkan dan tidak melaksanakan TOEFL. Selain itu, sebagian besar mahasiswa belum pernah mengikuti TOEFL sehingga hal ini membuat mereka bingung dan tidak mengerti bagaimana mengerjakan soal-soal TOEFL. Untuk mengetahui hal tersebut, salah satu Perguruan Tinggi swasta dipilih untuk dilakukan sebuah penelitian. Perguruan Tinggi tersebut adalah Universitas Kalimantan Utara (Kaltara). Universitas Kaltara merupakan sebuah Universitas Swasta yang berdiri di wilayah Provinsi Kalimantan Utara dan berlokasi di Ibukota Provinsi Kalimantan Utara, yaitu Tanjung Selor.

Berdasarkan hasil observasi diperoleh (1) Perguruan Tinggi tersebut belum pernah melaksanakan tes bahasa Inggris seperti TOEFL, (2) belum adanya kebijakan untuk 
penerapan mengikuti TOEFL sebelum lulus dan wisuda dari Universitas Kaltara, dan (3) sebagian besar mahasiswa Universitas Kaltara belum pernah mengikuti tes tersebut. Oleh karena itu, perlu dilakukan penelitian lebih lanjut mengenai studi tentang kemampuan mahasiswa Universitas Kaltara dalam mengerjakan soal TOEFL. Sesuai dengan latar belakang masalah tersebut, tujuan penelitian ini adalah untuk mengetahui kemampuan mahasiswa Universitas Kaltara dalam mengerjakan soal TOEFL mulai dari strategi, bentuk tes yang sulit dan mudah untuk dikerjakan hingga nila rata-rata TOEFL yang diperoleh oleh mahasiswa Universitas Kaltara. Pada penelitian ini menggunakan Paper-Based TOEFL (PBT) dikarenakan (1) keterbatasan sarana dan prasaran, seperti komputer dan (2) PBT lebih terjangkau dan paling banyak digunakan oleh pelajar/kalangan umum ketika mengikuti tes bahasa Inggris, seperti TOEFL. Selain itu, diperlukan analisis bentuk tes TOEFL apa saja yang mudah dan sulit dikerjakan atau dijawab oleh Mahasiswa Universitas Kaltara.

\section{METODE PENELITIAN}

Jenis penelitian yang digunakan pada penelitian ini adalah penelitian kualitatif. Menurut Denzin dan Lincoln dalam Borg et al. (2003:24), penelitian kualitatif adalah multi metode pada fokus penelitian yang dimiliki, melibatkan sebuah interpretasi, pendekatan naturalistic pada subjek penelitian. Hal ini bermaksud bahwa penelitian kualititatif mempelajari hal-hal dalam alur yang alamiah. Selain itu, Moleong (2014:6) menambahkan bahwa penelitian kualitatif adalah penelitian yang bermaksud untuk memahami fenomena tentang apa yang dialami oleh subjek penelitian, misalnya perilaku, persepsi, motivasi, tindakan, secara holitsik dan dengan cara deskripsi dalam bentuk kata-kata dan bahasa, pada suatu konteks khusus yang alamiah dan dengan memanfaatkan berbagai metode ilmiah. Adapun tempat pelaksanaan penelitian ini adalah kampus Universitas Kaltara, Tanjung Selor, Kabupaten Bulungan, Provinsi Kalimantan Utara.

Data adalah hal-hal yang berhubungan dengan kemampuan mahasiswa dalam mengerjakan soal TOEFL, yaitu strategi mengerjakan soal TOEFL, bentuk tes yang sulit dikerjakan pada soal TOEFL, dan bentuk tes yang mudah dikerjakan pada soal TOEFL. Jenis data dalam penelitian ini terdiri dari (1) populasi dan sampel, populasi yang dilibatkan pada penelitian ini adalah seluruh mahasiswa Universitas Kaltara yang sedang atau telah mengikuti perkuliahan mata kuliah Bahasa Inggris, sedangkan sampel meliputi 30 orang mahasiswa Fakultas Isipol, 30 orang mahasiswa Fakultas Ekonomi, 30 orang mahasiswa Fakultas Teknik Sipil, dan 10 orang mahasiswa Fakultas Matematika dan Ilmu Pengetahuan Alam. (2) Informan, yang dilibatkan adalah 2 orang mahasiswa Universitas Kaltara, Rektor Universitas Kaltara, dan Wakil Rektor Bidang Akademik Universitas Kaltara. Terakhir, (3) dokumen yang digunakan sebagai penelitian adalah soal-soal TOEFL yang telah dijawab oleh mahasiswa Universitas Kaltara.

Penelitian ini menggunakan teknik pengumpulan data berupa observasi, wawancara, dan analisis dokumen. Pada tahap observasi dilakukan dengan cara observasi nonpartisipan. Menurut Sugiyono (2013:204), dalam observasi partisipan peneliti tidak terlibat dan hanya sebagai pengamat independen. Peneliti akan mencatat, menganalisis, yang kemudian membuat kesimpulan tentang strategi mahasiswa Universitas Kaltara dalam mengerjakan soal TOEFL. Selanjutnya, pada tahap wawancara, teknik pengumpulan data yang digunakan melalui investigasi kepada seseorang dengan mengajukan beberapa pertanyaan yang berkaitan dengan penelitian kepada beberapa narasumber, yaitu Rektor Universitas Kaltara, Wakil Rektor I Bidang Akademik, dan 2 orang mahasiswa Universitas Kaltara. Wawancara ini juga dilakukan dalam bentuk 
wawancara tidak terstruktur. Menurut Sugiyono (2013:197) berpendapat bahwa wawancara tidak berstruktur adalah wawancara bebas yang peneliti tidak menggunakan pedoman wawancara yang telah tersusun sescara sistematis dan lengkap untuk pengumpulan datanya. Pedoman wawancara yang digunakan hanya berupa garis-garis besar permasalahan yang akan ditanyakan. Terakhir, adalah analisis dokumen yang digunakan untuk menganalisis hasil pekerjaan Mahasiswa Universitas Kaltara pada lembar jawaban test TOEFL yang peneliti akan menentukan tes apa yang sulit dan mudah dijawab oleh mahasiswa Universitas Kaltara serta nilai rata-rata TOEFL yang diperoleh. Adaptasi soal TOEFL yang akan dibagikan sesuai dengan jumlah dan struktur soal TOEFL pada umumnya, yaitu: (1) listening comprehension sebanyak 50 soal, (2) structure and written expression sebanyak 40 soal, dan (3) reading comprehension sebanyak 50 soal dengan durasi waktu sekitar 1 jam 15 menit untuk mengerjakan soalnya. Selain itu, soal akan diadopsi dari beberapa buku TOEFL yang relevan.

Analisis data kualititatif merupakan upaya yang dilakukan dengan jalan bekerja dengan data, mengorganisasikan data, memilah-milahnya menjadi satuan yang dapat dikelola, mensintensikannya, mencari dan menemukan pola, menemukan apa yang penting dan apa-apa yang dipelajari, dan memutuskan apa yang dapa diceritakan kepada orang lain (Bogdan \& Biklen dalam Moleong, 2014:248). Pada penelitian ini peneliti menggunakan analisis data menggunakan Miles and Huberman's model. Miles dan Huberman dalam Sugiyono (2013:48) menjelaskan bahwa aktivitas dalam menganalisis data kualitatif dilakukan secara interaktif dan berkelanjutan. Langkah-langkah dalam menganalisis data tersebut terdiri dari reduksi data, data display, dan conclusion drawing/verification (Sugiyono, 2013:338-345).

Data reduksi dimaksudkan untuk merangkum data, memilih isu utama, berfokus pada isu penting, dan menemukan bentuk dan mengurangi isu yang tidak penting. Oleh karena itu, data yang direduksi akan memberi gambaran yang jelas memudahkan peneliti untuk mengumpulkan data selanjutnya, dan mencarinya ketika dibutuhkan. Setelah direduksi, maka langkah selanjutnya adalah menyajikan data. Dalam penelitian kualitatif penyajian data (data display) dapat dilakukan dalam bentuk uraian singkat, bagan, hubungan antar kategori, flowchart, dan sejenisnya. Terakhir, dalam analisis data kualitatif adalah penarikan simpulan dan verifikasi. Simpulan awal yang dikemukakan masih bersifat sementasa, dan akan berubah bila tidak ditemukan bukti-bukti yang kuat yang mendukung pada tahap pengumpulan data berikutnya. Adapun gambar terkait dengan model Miles and Huberman ditampilkan pada Gambar 1.

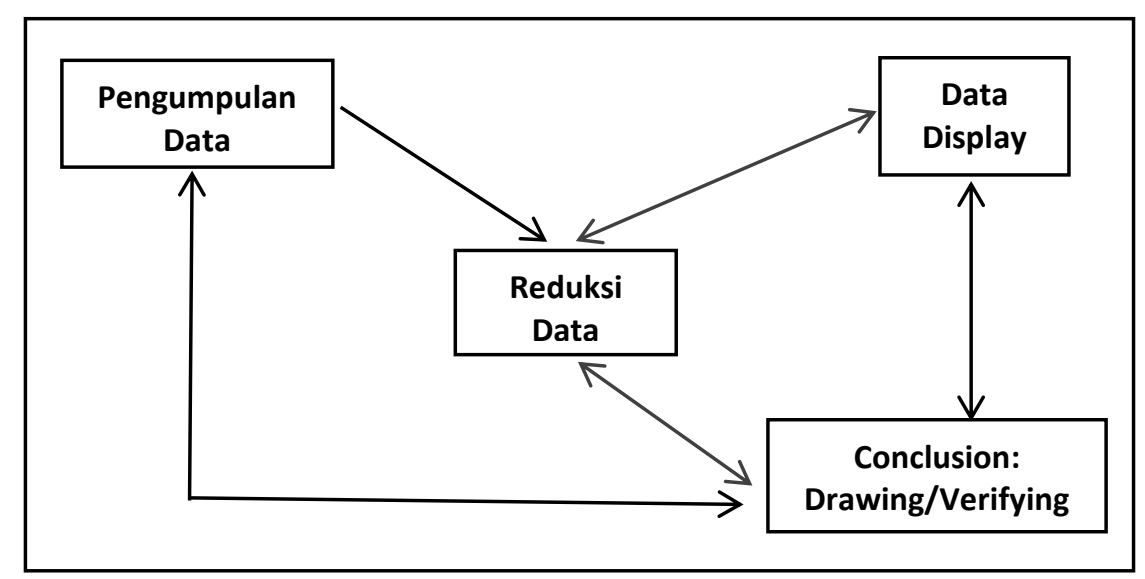

Gambar 1. Miles and Huberman Model (Interactive Model)

(Diadaptasi dari Sugiyono, 2013: 338) 


\section{HASIL DAN PEMBAHASAN}

\section{Bentuk Tes TOEFL}

Hasil penilaian tes yang telah dilaksanakan kepada mahasiswa Universitas Kaltara berdasarkan kesalahan dalam menjawab soal dapat dijelaskan dalam diagram berikut ini.

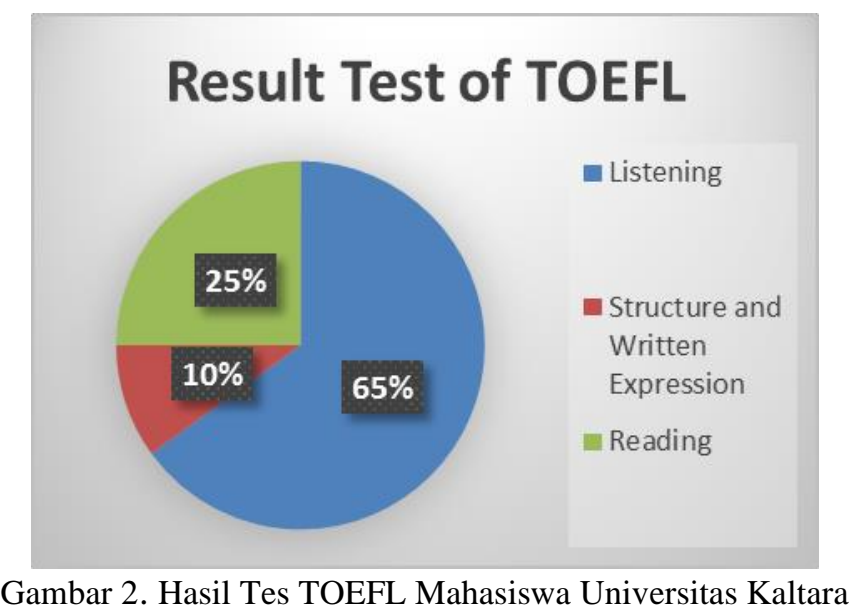

Pada diagram tersebut menunjukkan bahwa $65 \%$ mahasiwa mengalami kesulitan dalam mengerjakan soal listening, $10 \%$ pada soal structure and written expression, dan $25 \%$ pada soal reading. Hal ini diasumsikan karena kesulitan mahasiswa dalam memahami percakapan native speaker dari audio yang didengarkan dan hanya satu kali percakapan saja. Lebih lanjut, berdasarkan grafik tersebut juga dapat diasumsikan bahwa tes yang mudah dikerjakan dengan tingkat persentase paling terkecil (10\%), yaitu tes structure and written expression. Hal ini ditinjau dari kecilnya persentase kesalahan dalam mengerjakan soal TOEFL. Selain itu, hasil wawancara dengan dua mahasiswa Universitas Kaltara juga menyatakan bahwa soal tes structure and written expression relatif mudah untuk dikerjakan karena hanya berfokus pada ketelitian dalam melengkapi kalimat sesuai tata bahasa atau grammar secara tepat.

\section{Nilai Rata-rata TOEFL Mahasiswa Universitas Kaltara}

Hasil akhir penilaian tes TOEFL yang telah dikerjakan oleh mahasiswa Universitas Kaltara ditemukan bahwa rata-rata nilai yang diperoleh pada Tabel 3, yaitu sebagai berikut.

Tabel 3. Nilai Rata-Rata Hasil TOEFL Mahasiswa Universitas Kaltara

\begin{tabular}{lc}
\hline \multicolumn{1}{c}{ Section } & Score \\
\hline Listening & 38 \\
\hline $\begin{array}{l}\text { Structure and Written } \\
\text { Expression }\end{array}$ & 60 \\
\hline Reading & 40 \\
\hline
\end{tabular}

Dari Tabel 3 tersebut dapat diasumsukan bahwa nilai rata-rata tertinggi yang diperoleh oleh mahasiswa Universitas Kaltara adalah pada soal structure and written expression (60) dan selanjutnya reading (40) serta yang paling rendah, yaitu listening (38). Nilai rata-rata tersebut jika dikonversikan sebagai skor keseluruhan TOEFL, yaitu 
$(38+60+40) \times 10 / 3=460$. Berdasarkan skor tersebut masih dikategorikan standar minimal yang umumnya diperoleh oleh mahasiswa.

\section{Pembahasan}

Hasil penelitian menujukkan bahwa $65 \%$ mahasiwa mengalami kesulitan dalam mengerjakan soal listening, $10 \%$ pada soal structure and written expression, dan $25 \%$ pada soal reading, sedangkan tes yang mudah dikerjakan dengan tingkat persentase paling terkecil (10\%), yaitu tes structure and written expression. Menulis adalah kegiatan yang progresif. Selain itu, hal lain yang tidak kalah penting adalah penguasaan tata bahasa atau grammar. Harmer (2001:12) menjelaskan bahwa grammar adalah deskriptis dari cara yang mengolah kata-kata bisa mengubah bentuknya dan bisa dikombinaskan dalam kalimat-kalimat pada bahasa tersebut.

Adapun pemahaman membaca sebagai proses secara bersamaan mengukur dan membangun makna melalui interaksi dan keterlibatan dengan bahasa tertulis. Ada tiga unsur pemahaman bacaan, yaitu: (1) pembaca yang melakukan pemahaman; (2) teks harus dipahami, dan (3) aktivitas yang di dalamnya pemahaman adalah bagian (Snow, 2002: 11). Menurut peneliti, perlu adanya kajian khusus untuk meningkatkan strategi dalam memperoleh skor TOEFL pada tiap sesi yang diujikan. Para pembelajar sering kali mengalami kesulitan dalam menganalisis dan menentukan jawaban pada soal-soal TOEFL yang menggunakan bahasa Inggris.

Semakin efektif dipahami jika bahasa Inggris dalam semua keragaman bicaranya, kosa kata, struktur dan maknanya, semakin efektif akan menguntungkan secara pribadi dan berkontribusi pada pertumbuhan negara kita sebagai negara modern abad ke-21. Harmer (2001:1) menjelaskan bahwa walaupun bahasa Inggris bukanlah bahasa terbesar yang digunakan sebagai bahasa asli atau pertama, tetapi bahasa tersebut telah menjadi bahasa pengantar atau dikenal dengan istilah "lingua franca". Hal ini pun mendukung petingnya pembelajaran TOEFL bagi kebanyakan orang untuk mengukur kemampuan penguasaan bahasa Inggrisnya dengan berbagai tujuan.

\section{SIMPULAN}

Dari hasil penelitian dan pembahasan yang telah diuraikan, simpulan dari penelitian ini adalah strategi yang digunakan oleh mahasiswa Universitas Kaltara dalam mengerjakan soal TOEFL yaitu pertama listening, yang terdiri dari audio lingual method dan make a match, kedua structure and written expression, yang terdiri dari grammar translation method dan make a match, dan ketiga reading, yang terdiri dari scanning and skimming. Adapun tes yang paling sulit dikerjakan oleh mahasiswa Universitas Kaltara adalah pada soal listening yaitu sekitar 65\%. Hal ini diasumsikan karena kesulitan mahasiswa dalam memahami percakapan native speaker dari audio yang didengarkan dan hanya satu kali percakapan. Adapun tes yang mudah dikerjakan oleh mahasiswa Universitas Kaltara adalah tes structure and written expression. Hasil akhir dari nilai rata-rata TOEFL yang mampu didapatkan oleh mahasiswa Universitas Kaltara adalah 460 yang dikategorikan sebagai standar minimal.

Terkait dengan hasil skor TOEFL yang diperoleh mahasiswa Universitas Kaltara tersebut, maka perlu adanya kelas khusus dalam persiapan tes sebelum menghadapi tes TOEFL yang sebenarnya. Selain itu, kajian pemilihan soal-soal TOEFL perlu disesuaikan dengan kemampuan peserta yang akan mengerjakannya. 


\section{DAFTAR PUSTAKA}

Borg, Walter R., Gall, J.P., and Gall, M.D. (2003). Educational research; an introduction (7th edition). New York: Longman.

Genius Edukasi. (2015). Perbedaan jenis TOEFL PBT, CBT, dan IBT. Dikutip dari http://www.geniusedukasi.com/perbedaan-jenis-toefl-pbt-cbt-ibt/

Harmer, J. (2001). The practice of english language teaching (3rd edition). New York: Longman.

Ma, J. \& Cheng, L. (2015). Chinese students' perceptions of the value of test preparation courses for the TOEFL IBT: merit, worth, and significance. TESL Canada Journal/Revue TESL Du Canada Vol.33, Issuse 1, 2015. Pp. 58-79.

Moleong, L. J. (2014). Metode penelitian kualitatif (edisi revisi). Bandung: Rosda.

Oshima, A. \& Houge, A. (1997). Introduction to academic writing. New York: Longman.

Philips, D. (2001). Longman complete course for the TOEFL test. New York: Longman.

Saafin, S. (2014). Different performance of EFL university students on TOEFL and IELTS. AWEJ .5 (1). Pp.79-88.

Snow, C. E. (2002). Reading for understanding. Pittsburgh: RAND.

Stafford-Yilamz, L. \& Zwier, L. J. (2005). 400 must-have words for the TOEFL. New York: The McGraw-Hill Companies, Inc.

Sucahyo, S. A. (2016). Peta nilai TOEFL mahasiswa Program Studi Pendidikan Bahasa Inggris Institut Agama Islam negeri Samarinda. Fenomena, 8(1). Pp. 101-109.

Sugeng, B., Saleh, S.M., dan Suharto, G. (2010). Penguasaan bahasa Inggris mahasiswa baru UNY tahun akademik 2005/2006 - 2009/2010 pada kriteria TOEFL-Like. Laporan Penelitian Fakultas Bahasa dan Seni UNY: Staff.uny.ac. id.

Sugiyono. (2013). Metode penelitian pendidikan: pendekatan kuantitatif, kualitatif, and R\&D. Bandung: Alfabeta Publisher.

Sukur, S. G. (2013). Magic trick TOEFL ITP: magic trick menyelesaikan soal-soal TOEFL ITP ala sang pakar. Yogyakarta: Kalarana Press. 